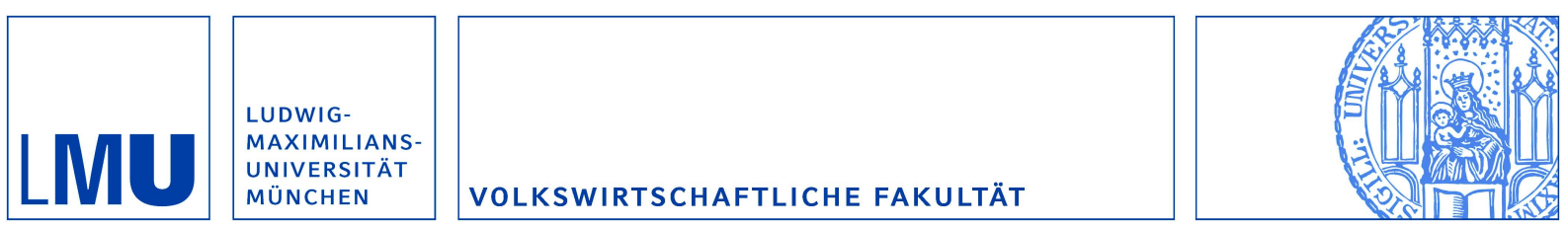

Fabbri, Francesca und Marin, Dalia:

What Explains the Rise in CEO Pay in Germany? A Panel Data Analysis for 1977-2009

Munich Discussion Paper No. 2012-12

Department of Economics

University of Munich

Volkswirtschaftliche Fakultät

Ludwig-Maximilians-Universität München

Online at https://doi.org/10.5282/ubm/epub. 12817 


\title{
What Explains the Rise in CEO Pay in Germany? A Panel Data Analysis for 1977-2009*
}

\author{
Francesca Fabbri, University of East Anglia \\ Dalia Marin, University of Munich
}

February 23, 2012

\begin{abstract}
The compensation of executive board members in Germany has become a highly controversial topic since Vodafone's hostile takeover of Mannesmann in 2000 and it is again in the spotlight since the outbreak of the financial crisis of 2009. Based on unique panel data evidence of the 500 largest firms in Germany in the period 1977-2009 we test two prominent hypothesis in the literature on executive pay: the manager power hypothesis and the efficient pay hypothesis. We find support for the manager power hypothesis for Germany as executives tend to be rewarded when the sector is doing well rather than the firm they work for. We reject, however, the efficient pay hypothesis as CEO pay and the demand for managers increases in Germany in difficult times when the typical firm size shrinks. We find further that domestic and global competition for managers has contributed to the rise in executive pay in Germany. Lastly, we show that CEOs in the banking sector are provided with incentives for performance and that the great recession of 2009 acted as a disciplining devise on CEO pay in Germany.

JEL Classification: F23, J3, M12, M52.
\end{abstract}

\footnotetext{
${ }^{*}$ We gratefully acknowledge financial support from the Deutsche Forschungsgemeinschaft through SFB/TR 15 and the European Commission under the FP7 Framework programme "SCience, Innovation, FIrms and markets in a GLObalized World (SCI-FI GLOW)". We would like to thank Joshua Angrist, Dirk Jenter and Gábor Körösi for helpful comments and Carola Frydman for providing us with US data on CEO pay. We also benefited from comments from presentations at University of Linz and SCIFIGLOW Meeting, Budapest.
} 


\section{Introduction}

The compensation of executive board members in Germany has become a highly controversial topic since Vodafone's hostile takeover of Germany's Mannesmann in 2000. Mannesmann's supervisory board chaired by Josef Ackermann approved nearly €60 million in bonuses and severance pay to Mannesmann's CEO Klaus Esser and other top executives. Executive compensation is again in the spotlight since the outbreak of the global financial crisis of 2008 as greedy CEOs in the financial industry are seen to have been taking on too much risks in pursuit of large profit gains. The anger over bonuses continued when troubled financial institutions such as HypoRealEstate, Bayerische Landesbank, WestLB, and Dresdner Bank paid out large bonuses despite facing bankruptcy and being saved by tax payers' money. In March 2009 Germany's federal finance minister called for a return of Dresdner Bank's 2008 “obscene bonuses". In response to the public outrage car-maker BMW announced that their executive remuneration will be linked to blue-collar salaries (Lawton (2009)). In 2009 the German government announced new rules limiting banking bonuses. French president Nicolas Sarkozy urged leaders of the world's top 20 developed nations (G20) to follow suit. ${ }^{1}$

Due to lack of data, the debate on executive pay in Germany has remained anecdotal and has not been based on solid data. This paper tries to fill this gap. Based on panel data evidence of the 500 largest firms in Germany in the period of 1977 to 2009, we document the basic stylized facts of CEO pay in Germany and its determinants in the last three decades. We then examine the following issues. First, is CEO pay in financial institutions systematically different from the rest of the economy? Second, is the recent financial crisis different in terms of compensation compared to previous recessions? Finally, we test two hypotheses which have gained importance in the theoretical literature on executive

\footnotetext{
${ }^{1}$ See "Call for Dresdner execs to return bonuses get mixed response", Banking Newslink, March 31, 2009; "Germany's BaFin Clamps Down On Bank Risk Mgmt, Bonuses" , Dow Jones International News, August 14, 2009; "France announces bank bonus crackdown and urges G20 nations to follow suit", The Guardian, August 26, 2009.
} 
pay: the manager power hypothesis on the one hand and the efficient pay hypothesis on the other. The managerial power hypothesis (Bebchuk and Fried (2003)) assumes that executives are self-interested, and are able to influence the level of their own compensation packages often at the expense of shareholders. According to this view, the level and composition of pay are determined not by competitive market forces but rather by captive board members catering to rent-seeking entrenched CEOs. On the other hand, CEO pay can be used to alleviate the agency problems between shareholders and managers by aligning their interests. This typically takes the form of performance based remuneration or of granting executives an ownership stake in the firm. According to the efficient pay hypothesis formulated by Gabaix and Landier (2008), the marginal product of managerial ability increases with firm size and it optimally assigns the most talented managers to the largest firms. Therefore, as the average firm becomes larger, managerial marginal products increase and competition for scarce managerial talent will bid up compensation of CEOs. Accordingly, CEO pay should move one-for-one with changes in the size of the typical firm.

The findings of our empirical analysis can be summarized as follows. First, we find support for the manager power hypothesis for Germany as executive compensation packages do not involve incentives for performance. German CEOs tend to be rewarded when the sector is doing well rather than the firm they work for. We reject, however, the manager power hypothesis for the financial sector and for the latest recession in 2009. Second, we reject the efficient pay hypothesis. Increases in the typical firm size do not appear to contribute to increases in CEO pay in Germany. On the contrary, we find that CEO pay and the demand for manager talent increases in difficult times when the typical firm size shrinks, perhaps in an attempt of the firm to optimally limit losses. Third, we find evidence that domestic and global competition for managers has contributed to the rise in executive pay in German. Surprisingly, however, the impact of competition for managers on executive compensation has become weaker in the last two decades. Fourth, 
the effect of local and global competition for managers is particularly pronounced in the banking sector and has become much more intense in the last two decades after German unification.

The paper is organized in the following sections. Section 2 describes the data. Section 3 documents the evolution of executive pay in Germany in the last three decades with a particular focus on the question whether the recent financial crisis in 2009 has been unique in terms of compensation. Section 4 presents the framework and empirical results. Section 5 introduces a dynamic panel analysis to examine problems of endogeneity. Section examines whether the financial sector has behaved differently in terms of compensation, while section 6 concludes. A data appendix gives a documentation of the data and descriptive statistics.

\section{Data and Institutional Background}

Our empirical analysis is based on data from the consulting firm Kienbaum. Kienbaum is a management consultancy specialised in remuneration policies which collects annual information on executive compensation of large German firms since 1976. The data contains information on total compensation of the executive board, number of executive board members, annual net (after-tax) profits, balance sheet totals ${ }^{2}$ (for banks), premia (for insurance companies) and sales (for industry and services) ${ }^{3}$. Although Kienbaum started collecting data in 1976, information on profits is available from 1977. Consequently, our analysis covers the period from 1977 to 2009, 2009 being the last available year at the time of writing. Information on number of workers is also provided, however only from 1988. Generally, balance sheet totals, sales, premia and number of workers refer to the size of the public limited company $(A G s)$ or, if it is a controlling company, to the size

\footnotetext{
${ }^{2}$ Balance sheet totals are measured by assets, liabilities and ownership equity listed as of a specific date.

${ }^{3}$ In the original data set, values are in German Marks until 1999 and have been converted to Euros.
} 
of the consolidated company ${ }^{4}$. Each year, our sample contains on average 19 per cent banks, 16 per cent insurance companies, and 65 per cent of firms in the manufacturing and services sector.

The value of executive board remuneration includes monetary and non-monetary compensations, therefore values of (fringe) benefits (as long as they are taxable), long- and mid-term incentives (stock options, performance shares, restricted stocks etc.), short-term incentives (profit participation on annual profits, mainly results-oriented royalties) and fixed salary. According to Kienbaum, stock option grants have been evaluated by the companies' auditors. We conducted detailed research ${ }^{5}$ on a small sub-sample of the largest publicly quoted firms, to understand how this evaluation is conducted. Our research indicates that stock option grants are not usually consistently evaluated, neither between nor within firms (over time). It is worth noting, however, that stock option grants have been an uncommon pay component in the remuneration package of CEOs of German firms until the end of the 1990s. In practice, before 1998, German law made performance-related pay difficult to implement and only a few very large companies (such as Deutsche Bank and Daimler Benz) are known to have provided such type of payments to their CEOs before that date ${ }^{6}$.

More detailed (but still limited) information on composition of CEO compensation is available from 2005 and for a selected number of firms. ${ }^{7}$ To keep the long time dimension of our data set, we need to rely on the information on total compensation of the executive board within a company. Using information on the number of CEO members, we derive our variable of interest, average yearly per capita remuneration inside the board.

\footnotetext{
${ }^{4}$ Balance sheet total is commonly used to measure enterprise size (see the European Commission Recommendation 2003/361/EC of 6 May 2003 concerning the definition of micro, small and mediumsized enterprises, European Commission (2003)).

${ }^{5}$ Available on request.

${ }^{6}$ See Martens (2003) for a detailed account of changes in German law regulating compensation in the form of stock options.

${ }^{7}$ This change follows the 2005 Vorstandsvergütungs-Offenlegungsgesetz, a law requiring the public disclosure of compensation of executive board members. This law, however, has been implemented only in a handful of Bundesländer at the time of writing.
} 
The Kienbaum data set is a unique source of information on executive remuneration in Germany. The main advantages of the data set are its large sample size, long time span, and coverage of the banking sector. Information on executive compensation is available at a very aggregate level (break-down by board members and by type of salary is available only from 2005) and information on firms is limited to balance sheets, sales, premia, profits and number of workers.

The Kienbaum sample includes the largest 100 firms (according to the German stock index and similar indexes calculated by the Deutsche Börse, discussed below) and about 1000 corporations (Aktiensgesellschaften or AGs) and large limited liability companies (Gesellschaften mit beschrankter Haftung or GmbHs). The data set is an unbalanced panel. Over 94\% companies are observed at least twice and 37 companies have been followed through the entire period. Generally, information on fewer than 1000 firms is collected before the 1980s. After 1981, sample size fluctuates between 1000 and 2000 observations.

A specific sampling scheme is not followed through the years. This potentially creates a problem in the statistical analysis if, for example, some results are driven by the exogenous inclusion of smaller companies in some years rather than others ${ }^{8}$. Furthermore, for the same reason we cannot establish whether an entrance in (exit from) the data corresponds to an entrance in (exit from) the market.

For these reasons, we choose to focus on those companies which were among the largest 500 in at least one of the years under investigation. We identify the largest companies using as a measure of size the value of balance sheet total for banks, insurance premia for insurance companies and sales for firms in the industry and service sectors. We also include companies listed by the Deutsche Börse according to one of its main stock indexes ${ }^{9}$. This

\footnotetext{
${ }^{8}$ As a matter of fact, we see this in the data, when analysing mean trends of profits and of CEO compensation. In 1982 and following years, when about 300 more companies were added to the sample, mean profits and compensation appear significantly lower than in 1981. This however appears to be due to the increase in sample size, rather than an actual decrease in the means following some economic downturn (see analysis below).

${ }^{9}$ The German stock market index DAX measures the performance of the Prime Standard's 30 largest
} 
sampling restriction has two main advantages. First, it helps mitigating potential biases due to the (for our purposes) arbitrary sampling scheme adopted by Kienbaum. Second, it makes our data set more suitable for comparisons with dominant US literature (where the focus is usually on the top 500 corporations).

The German case is particularly interesting because corporate governance differs greatly from the US. German corporate governance is characterised by the presence of co-determination (Mitbestimmung): in all publicly quoted companies (Aktiengesellschaft), the executive board is nominated by the supervisory board (Aufsichtsrat or board of directors), whereby members of the supervisory board are representatives of workers and of shareholders. Although in case of disagreement the representative of the major stockholder will have the final say, the consequences of this "two-tier" system may represent a stronger control on compensation of the executive board than the "one-tier" system in the US. Such corporate differences imply that theoretical and empirical results based on US evidence may not necessarily apply toGermany.

\section{$3 \quad$ Stylized Facts}

We start documenting the trend in CEO pay in Germany in need of explanation. Figure 1, Panel (a) shows the mean of CEO compensation for the total board as well as per board member at 2006 prices for the 500 largest German firms in the period 1977-2009. Red vertical lines indicate official recession dates as given by the German National Statistical office. It appears that the time pattern of CEO pay is characterized by three distinct periods. In the period 1977-1982 CEO pay was basically flat or declining, in 1983-1992 real compensation started to increase by 4 percent annually followed by a steep increase

German companies trading on the Frankfurt Stock Exchange in terms of order book volume and market capitalization. The other indexes used by Kienbaum to select companies are the MDAX and TecDAX. The MDAX includes the 50 Prime Standard companies from classic sectors (i.e., excluding the technology sector) that rank immediately below the companies included in the DAX index. The TecDAX includes the 30 largest German companies from the technology sector that rank immediately below the companies included in the DAX index. 
in 1992-2000 with an annual increase of 10 percent. Finally, in 2001-2009 CEO pay first declined when the dot com bubble burst in 2001-2002 to increase sharply in 2003 with a strong decline again in the financial crisis of 2008-2009. Over the entire period 1977-2007 CEO pay per head increased in real terms (at 2006 prices) from over $€ 200.000$ to almost $€ 700.000$ which is a 3.5 fold increase. This is substantial, indeed, but not as dramatic an increase as in the US. ${ }^{10}$

Figure 1: Board Compensation, 1977-2009

\section{All Firms}

(a) Mean across Firms

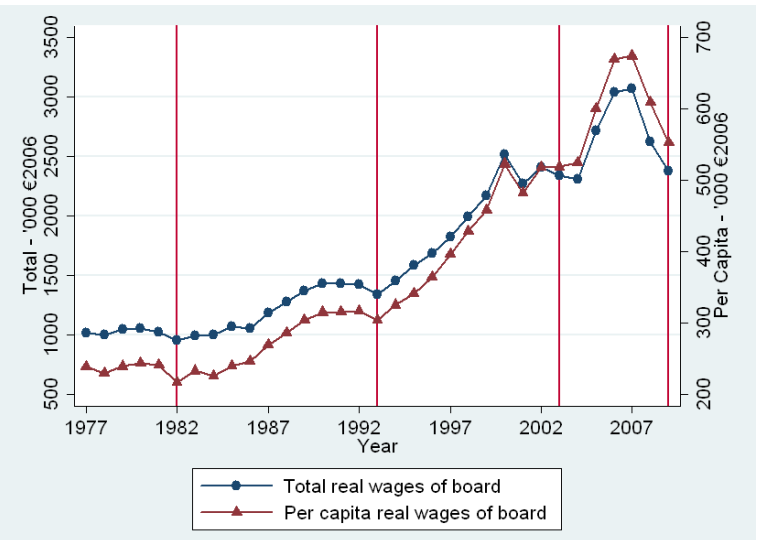

(b) Selected Percentiles

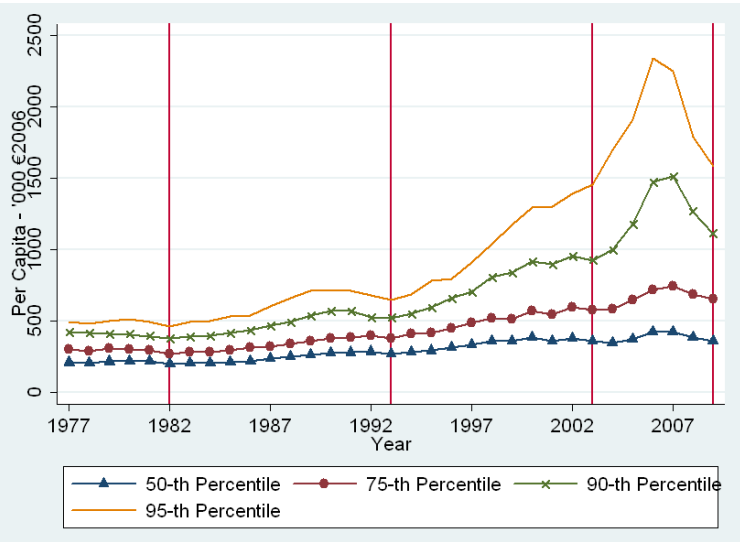

Note: Vertical bars indicate official recession years in Germany. Pay levels (in 2006-constant Euros) based on data for 500 largest public and limited liabilities companies. Total remuneration defined as the sum of salaries, bonuses, benefits, stock options, stock grants, and other compensation. Percentiles are evaluated for per capita real wages of board only.

Panel (b) of Figure 1 - showing selected percentiles of CEO pay per board member documents that the increase in compensation since the beginning of the 1990s is largely due to an increase of the best paid CEOs. CEO pay of the top 5 percent earners has increased from about $€ 500.000$ to $€ 2.3$ mio (a more than 4.5 fold increase) while those of the bottom earners only doubled during 1992-2007. As a result, the explosion of CEO

\footnotetext{
${ }^{10}$ In comparison CEO pay in the US increased six-fold in 1980-2003, see Frydman and Saks (2010). Interestingly, nominal compensation in Germany steadily increased in every year except of the latest two recession periods. This suggests that in the past, even in difficult times, firms have rarely reduced nominal compensation of board members.
} 
pay since the beginning of the 1990s is accompanied by a stark increase in the variance of pay among executives. ${ }^{11}$

In Panel (a) and (b) of Figure 2 we look at the trend of the mean and median of net real profits and firms size as possible determinants of CEO pay. Mean and median firm size steadily increased over the entire period, seemingly giving initial support to the efficient pay hypothesis, which claims that the shift in the entire distribution of firms leads to a proportional shift in compensation. However, median firm size increased from $€ 250$ mio in 1977 to about $€ 1.3$ billion which is a 5.2 fold increase, while median compensation per board member increased only 1.8 fold, suggesting that other determinants may have played a role for the evolution of compensation in Germany. Net real profits, an indicator for firm performance, have increased somewhat over the period 1992-2007 but have exhibited much more volatility compared to CEO pay during the same period suggesting that CEO pay may not entirely be driven by firm performance, giving first support to the manager power hypothesis.

We turn now to the wage gap between CEO earnings and wages of white collar workers to show changes in the income distribution among skilled workers. Figure 3 plots the ratio between CEO compensation (including salaries, bonuses, benefits, stock options and grants as well as other compensation) and average wages of white collar workers. ${ }^{12}$ This ratio more than doubled: in 1977 per capita compensation was 8 times white collars' average wages and increased to 17 times in 2007. Note that CEO premium remains almost flat until 1992 to then steeply increase between 1993-2002 with an even steeper increase in the period 2004-2007. Note also that the overall change in the income distribution appears to have been driven to a large extent by a shift in the income distribution within

\footnotetext{
${ }^{11}$ As CEO pay increased sharply among the best paid CEOs the median is a more useful measure than the mean of the typical CEO in a particular year.

${ }^{12}$ The data for wages of white collar workers come from the Quarterly Earning Survey of the German Federal Statistical Office which is based on a representative one-stage stratified sample for which response is compulsory. The data is only available until 2008 at the time of writing. See the Data Appendix for more information.
} 
Figure 2: Profits and Firm Size - 1977-2009

\section{All Firms}

(a) Mean across Firms

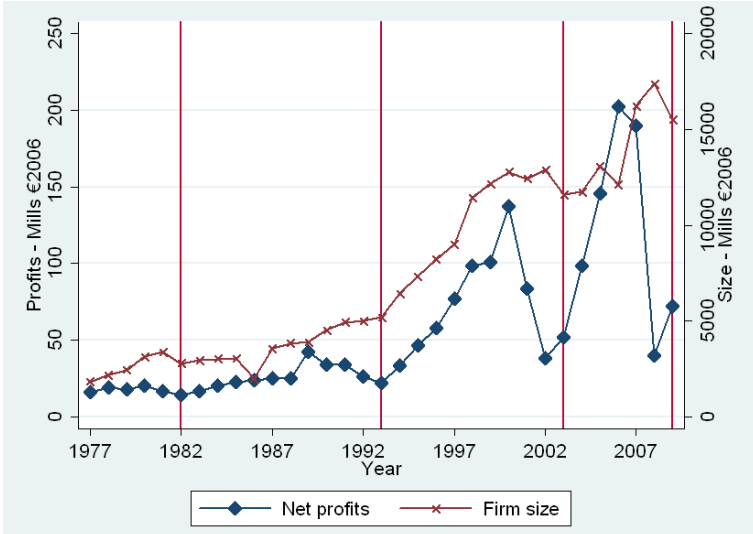

(b) Median across Firms

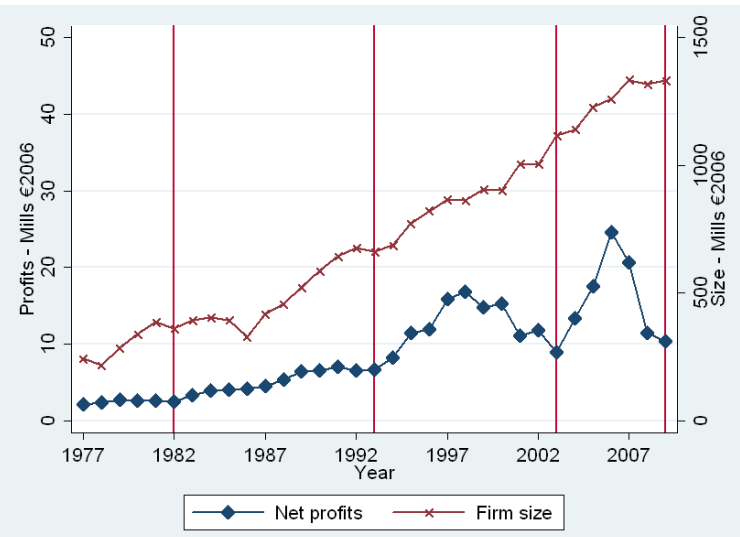

Note: Vertical bars indicate official recession years in Germany. Profits and size (in 2006-constant Euros) based on data for 500 largest public and limited liabilities companies. Profits are after tax. Size defined as balance sheet totals (banks), insurance premia (insurance companies), and sales (manufacturing and other services).

Figure 3: Earnings Gap, 1977-2008: Ratio of per-Capita Board Compensation to Average Earnings

(a) All Firms

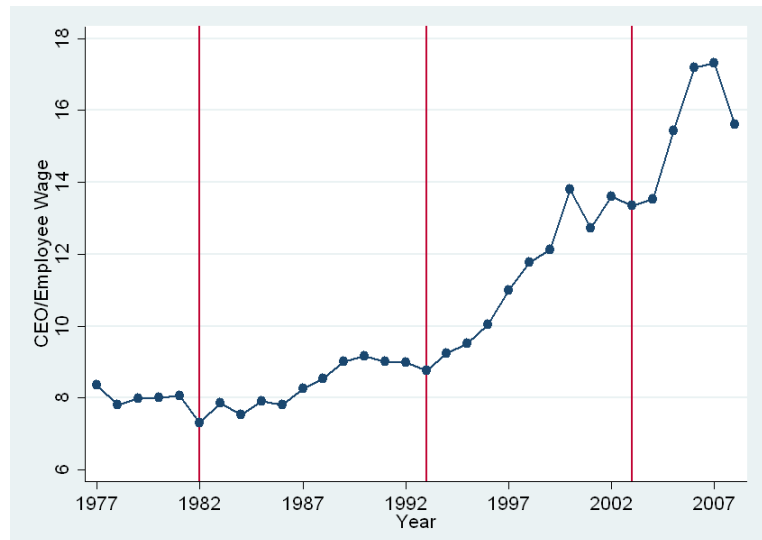

Note: Vertical bars indicate official recession years in Germany. Remuneration (defined as the sum of salaries, bonuses, benefits, stock options, stock grants, and other compensation) is calculated as the total compensation of the executive board divided by the size of the board. In panel (b), the ratio is calculated with respect to average wage of financial sector employees. Source: Kienbaum compensation data and German Quarterly Earnings Survey. 
the group of skilled workers rather than between skilled and unskilled worker. ${ }^{13}$

\subsection{Is CEO Pay in the Great Recession different from previous Recessions?}

We turn now to the financial crisis of 2008-2009. Anecdotal evidence in the business press suggests that in the recent global financial crisis the link between CEO pay and performance is missing. The public outrage over pay-outs of bonuses in firms facing financial difficulties have been seen as evidence that compensation is not based on performance. In response to the public anger over bonuses Lloyd Blankfein of Goldman Sachs and Josef Ackermann of Deutsche Bank among other executives declared they would forego their bonuses in 2009. In this section we start looking at whether compensation in Germany in the financial crisis of 2008-2009 has been indeed different from previous recessions.

Figure 4 shows relative changes in CEO compensation, profits, and firm size in the three years leading to the recessions in 1982, 1993, 2003 and 2009. The largest drop in CEO pay indeed occured during the latest great recession of 2009, when CEO pay fell by about 18 percent compared to 11 percent in 1982 and virtually no changes in the recessions of 1993 and 2003. In contrast, in 2009 firms' economic performance as measured by profits was not much worse than in the recession of 2003 and recovered much faster in 2009. This suggests that the public outcry over compensation in the great recession of 2008-2009 does appear to have imposed a stronger link between CEO remuneration and firm performance compared to previous recessions. Thus, descriptive evidence appears to suggest that the link between compensation and performance has become stronger in the latest recession. We examine this question in greater detail in the next section.

\footnotetext{
${ }^{13}$ See Dustmann et al. (2009) for an analysis of changes in the wage structure in Germany. Evidence from Dustmann et al. (2009), Piketty and Saez (2006) and Dell (2005) is consistent with the idea that shifts in the income distribution in the US and Germany are largely a phenomenon among the rich.
} 
Figure 4: Relative Changes in the Three Years leading to German Recessions - Total Economy

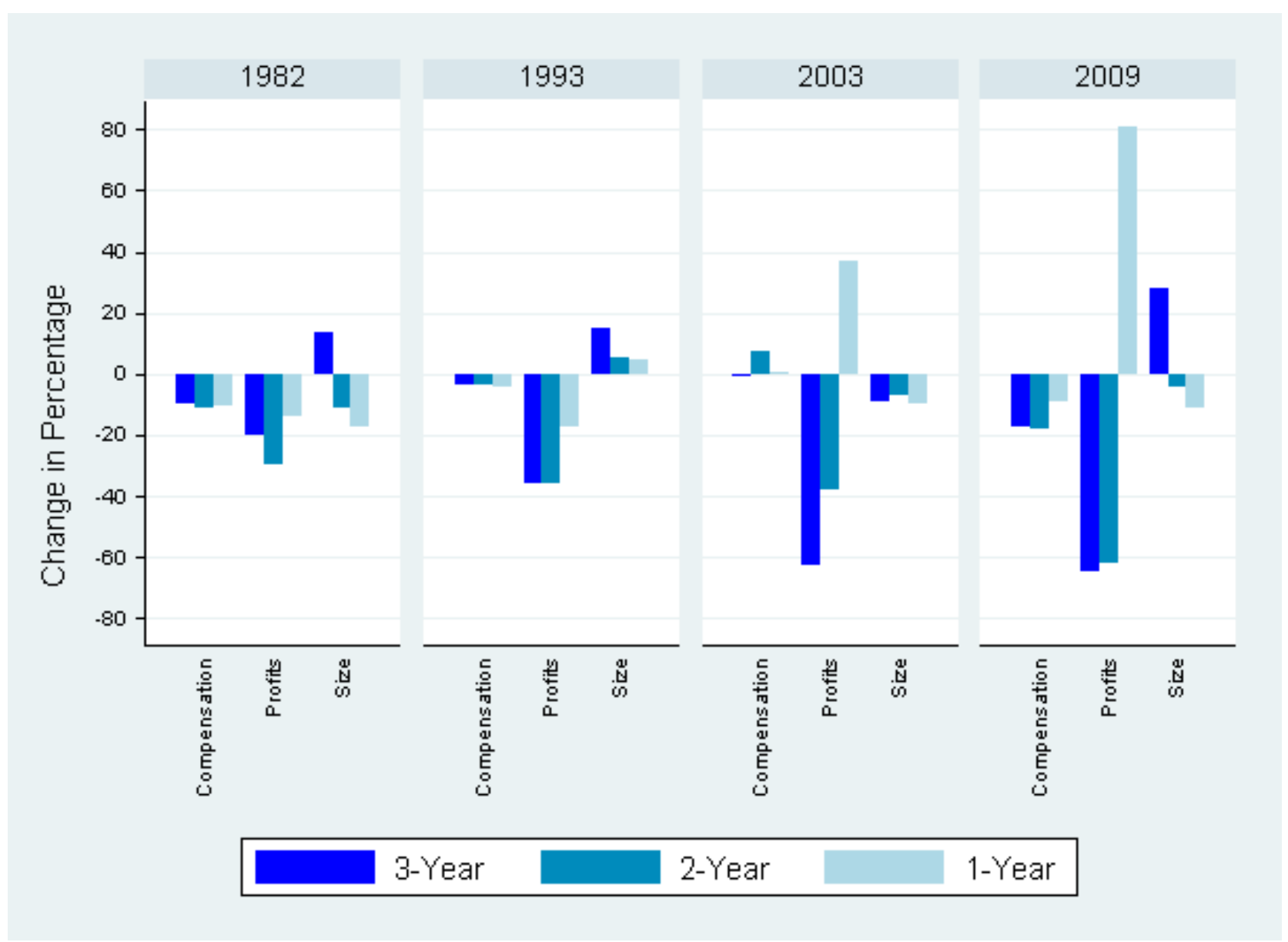

Note: Official recession years in Germany are 1982, 1993, 2003 and 2009. $t$-year difference is constructed subtracting the value of the relevant variable $t$ years before the relevant recession from the value corresponding to the year of recession. For percentage change, this difference is divided by the value in the $t$-th year before the relevant recession. Source: Kienbaum compensation data. 


\section{Empirical Framework and Results}

We turn now to a more rigorous analysis of CEO pay in Germany to substantiate the stylized data given in section 3. In particular we want to test the two most prominent hypotheses of the CEO literature: the manager power hypothesis and the efficient pay hypothesis. The manager power hypothesis assumes self-interested executives which are able to influence the level of their own compensation packages often at the expense of shareholders. If this hypothesis is valid we do not expect CEO pay to be strongly correlated to firms' performance. We test this hypothesis by examining how sensitive CEO pay is to firm performance. According to the efficient pay hypothesis the marginal product of managerial ability increases with firm size and it is optimal to assign the most talented managers to the largest firms. Executives of larger firms receive higher compensation. In addition, as the average firm becomes larger, managerial marginal products increase and competition for scarce managerial talent will bid up compensation of CEOs. We test the hypothesis by examining how responsive CEO pay is to firm size and whether CEO pay increases as the average firm becomes larger in the market.

We estimate the following basic equation

$$
\ln \left(C_{i t}\right)=\sum_{j=0}^{1} \beta_{\mathbf{j}}^{\prime} \mathbf{X}_{\mathbf{i t}-\mathbf{j}}+\sum_{j=0}^{1} \gamma_{\mathbf{j}}^{\prime} \overline{\mathbf{X}}_{\mathbf{t}-\mathbf{j}}+\eta_{i}+\alpha_{1} t+\alpha_{2} t^{2}+\varepsilon_{i t}
$$

where $C_{i t}$ is compensation per board member in company $i$ in year $t$. Compensation is measured in real terms in thousands of 2006 Euros; $\mathbf{X}_{\mathbf{i t}}$ indicates firm characteristics such as number of board members $\left(\right.$ No.Board $\left._{i t}\right)$; log of firm size $\left(S_{i t}\right)$, and firm net profits $\left(\pi_{i t}\right)$, both measured in millions of 2006 Euros. $\overline{\mathbf{X}}_{\mathbf{t}}$ is a vector of average market variables capturing the characteristics of a typical firm in the market in year $t^{14}$. These include:

\footnotetext{
${ }^{14}$ We experimented using different sets of lagged regressors, to account for the possibility that (a combination of) past firm characteristics may affect CEO pay. Results, however, are not significantly different from those reported below.
} 
firm size $\left(\bar{S}_{t}\right)$, workers' wages $\left(\bar{W}_{t}\right)$, CEO pay $\left(\bar{C}_{t}\right)$, and annual average remuneration of the top three CEOs in large US companies $\left(\bar{C}_{t}^{U S}\right)^{15}$. This specification implies that the coefficient on profits $\pi(S)$ measures how strongly CEO pay responds to relative performance (size) of the firm with respect to the rest of the market and the coefficient on average profits (firm size), $\bar{\pi}(\bar{S})$ tests for whether CEO pay responds to an increase in typical firm profits (size) in the market. We include average workers' wages $\left(\bar{W}_{t}\right)$ to test explicitly for a tight local labour market. We also include average CEO pay $\left(\bar{C}_{t}\right)$ and annual average remuneration of the top three CEOs in large US companies $\left(\bar{C}_{t}^{U S}\right)$ to measure to what extent competition for local $\left(\bar{C}_{t}\right)$ and global managers $\left(\bar{C}_{t}^{U S}\right)$ can explain CEO pay. $t\left(t^{2}\right)$ is a time trend to account for linear (quadratic) growth of CEO pay and time trending market variables; $\eta_{i}$ is an unobserved firm fixed effect. Table 5 in the Appendix describes all variables in detail. Table 6 provides summary statistics.

In a first step (Table 1) we estimate specification (1) using only contemporaneous regressors. In a second step (Table 2), we estimate specification (1) in full, using also lagged regressors. Comparing estimates from the two sets of results should help us in better understanding the "reaction time" of CEO compensation with respect to changes in firm and market characteristics.

Table 1 has the following structure. Columns (1) to (3) show results for the entire period 1977-2009. Columns (4) to (8) display results for the period 1977-2005, where the last three years of our sample are dropped because information on US CEOs is available only until $2005^{16}$. Columns (9) to (10) display results for the shorter period 1990-2009 to help us establish if any substantial change in the determinants of CEO compensation happened after German re-unification. We control for size of the board in all specifications of Table 1 , since our measure of CEO compensation is the average pay per board member. We

\footnotetext{
${ }^{15}$ Information for the US CEOs was kindly provided by Carola Frydman (MIT). Data is based on the largest 50 firms according to Frydman and Saks (2010) and is available until 2005.

${ }^{16}$ Column (4) reports the same specification as of column (3), but until 2005 only. This is to provide consistency in the sample used. In particular, a comparison between columns (3) and (4) indicates that the drop in significance of firm profits is due to the exclusion of the last 3 years of the sample, rather than to the inclusion of average firm characteristics and US compensation.
} 
control for average profits in the market to estimate how CEO compensation is affected by relative rather than absolute firm performance. The estimated correlation between profits (measured for convenience of exposition in billions of Euros in the regression) and CEO compensation is between 0.095 and 0.084 depending on the specification and it is significant at the 5 percent level. ${ }^{17}$ This implies that an increase in firm relative profitability of 1 million Euros increases CEO compensation by 0.009 percent. The significant and positive coefficient on average profits in column (2) suggests that German CEOs tend to be (at least partly) compensated independently of their own firm's performance, as their pay increases by 0.06 percent when average profits in a sector increase by 1 million Euros. It appears then that the incentives created by compensation packages in German firms tend to be small and weakly aligned to the interests of shareholders.

In the literature on $\mathrm{CEO}$ pay there is a debate on the economic interpretation of why the estimated coefficient on profits may turn out to be small. Jensen and Murphy (1990) argue that CEOs in the US are paid like bureaucrats, since they are primarily paid for increasing the size of their organization and receive small rewards for superior performance. More recently, however, Hall and Liebman (1998) have questioned that low pay for performance sensitivities are in fact measuring low incentives. They argue that, since firm size has increased over time, the dollar change in CEO pay for a dollar change in profits dramatically underestimates how much executives gain from improving firm performance. Executives tend to own smaller percentage (and larger dollar) stakes in larger firms with the result that firm growth leads to a lower pay for performance sensitivities. 18

However, in our estimates the coefficient on profits becomes even smaller and stops to be statistically significant once the years of the financial crisis are excluded from the

\footnotetext{
${ }^{17}$ In the regression, profits are measured in billion of euros to obtain meaningful coefficients. The discussion that follows, though, reports results in terms of changes in million of Euros because the changes in profits documented in our data set are in this order of magnitude.

${ }^{18}$ See Frydman and Jenter (2010) for a discussion and a comparison between the Jensen and Murphy measure of a dollar change in CEO pay for a dollar change in profits and the Hall and Liebman measure of a dollar change in CEO pay for a percentage change in profits.
} 
sample as in (columns (4) to (8)). This indicates that incentives appear not to have played a significant role before 2006. These findings support the casual impression of Figure 7 that the sharp drop in profits in the great recession acted as an disciplining devise which was linking CEO compensation back to firm performance in response to the the public outrage over CEO compensation.

In column (2) we add firm size to examine whether larger firms pay their CEOs more. The evidence indeed is supportive. A 1 percent increase in firm size increases CEO pay by about 0.2 percent and the relationship is significant at the 1 percent level. Reported results are consistent with previous evidence on CEO pay in the US and Germany. The explanation for this being that CEO talent is valued more in larger firms where talent is most productive. ${ }^{19}$

Next, we turn to a test of the efficient pay hypothesis in column (3). Interestingly, we find that CEO pay declines (rather than increases) as typical firm size $\bar{S}_{t}$ increases. This finding is difficult to reconcile with the efficient pay hypothesis. One possible interpretation is that German firms increase the quest for manager talent when the economy shrinks rather than when it expands as CEO effort is more in demand when firms go through difficult times to find ways to mitigate losses and to recover faster. Note, however, that in column (10) the coefficient of $\bar{S}_{t}$ turns positive and becomes significant (albeit only at the $10 \%$ level) in the latest period of 1990-2005. One possible explanation for the change in this relationship could be that after re-unification German firms became much more exposed to international trade. The trade to GDP ratio almost doubled between 1990 and 2005 suggesting that increased international trade may have played a role. ${ }^{20}$

In columns (5) to (8) we test more explicitly whether CEOs are paid more in face of a tighter labour market in general (an increase in $\bar{W}_{t}$ ), a tighter market for local manager talent (an increase in $\bar{C}_{t}$ ) or a tighter market for global manager talent (an

\footnotetext{
${ }^{19}$ Among others, see Murphy (1999), Conyon and Schwalbach (2000) and Gabaix and Landier (2008).

${ }^{20}$ For the role of international trade for the rise in CEO pay see Marin and Verdier (forthcoming) and Marin (2009).
} 
Table 1: CEO Pay and Firm Characteristics: Fixed Effects - All Sectors

\begin{tabular}{|c|c|c|c|c|c|c|c|c|c|c|}
\hline & \multicolumn{3}{|c|}{ 1977-2009 } & \multicolumn{5}{|c|}{ 1977-2005 } & \multicolumn{2}{|c|}{ 1990-2005 } \\
\hline & (1) & $(2)$ & (3) & (4) & (5) & (6) & $(7)$ & (8) & (9) & (10) \\
\hline No.Board $_{i t}$ & $\begin{array}{c}-0.051^{* *} \\
(0.006)\end{array}$ & $\begin{array}{c}-0.065^{* *} \\
(0.007)\end{array}$ & $\begin{array}{c}-0.065^{* *} \\
(0.007)\end{array}$ & $\begin{array}{c}-0.062^{* *} \\
(0.007)\end{array}$ & $\begin{array}{c}-0.063^{* *} \\
(0.007)\end{array}$ & $\begin{array}{c}-0.063^{* *} \\
(0.007)\end{array}$ & $\begin{array}{c}-0.062^{* *} \\
(0.007)\end{array}$ & $\begin{array}{c}-0.063^{* *} \\
(0.007)\end{array}$ & $\begin{array}{c}-0.063^{* *} \\
(0.010)\end{array}$ & $\begin{array}{r}-0.063^{* *} \\
(0.010)\end{array}$ \\
\hline$\pi_{i t} / 1000$ & $\begin{array}{c}0.095^{*} \\
(0.042)\end{array}$ & $\begin{array}{c}0.084^{*} \\
(0.038)\end{array}$ & $\begin{array}{c}0.084^{*} \\
(0.038)\end{array}$ & $\begin{array}{c}0.061 \\
(0.043)\end{array}$ & $\begin{array}{c}0.061 \\
(0.043)\end{array}$ & $\begin{array}{c}0.062 \\
(0.043)\end{array}$ & $\begin{array}{c}0.061 \\
(0.043)\end{array}$ & $\begin{array}{c}0.061 \\
(0.043)\end{array}$ & $\begin{array}{c}0.054 \\
(0.041)\end{array}$ & $\begin{array}{c}0.054 \\
(0.041)\end{array}$ \\
\hline $\bar{\pi}_{t} / 1000$ & $\begin{array}{l}0.589^{* *} \\
(0.084)\end{array}$ & $\begin{array}{l}0.571^{* *} \\
(0.079)\end{array}$ & $\begin{array}{c}0.601^{* *} \\
(0.078)\end{array}$ & $\begin{array}{l}0.592^{* *} \\
(0.130)\end{array}$ & $\begin{array}{c}0.383^{*} \\
(0.150)\end{array}$ & $\begin{array}{c}-0.014 \\
(0.156)\end{array}$ & $\begin{array}{c}0.014 \\
(0.156)\end{array}$ & $\begin{array}{c}0.452^{* *} \\
(0.165)\end{array}$ & $\begin{array}{c}0.446^{*} \\
(0.206)\end{array}$ & $\begin{array}{c}0.437^{*} \\
(0.206)\end{array}$ \\
\hline $\ln S_{i t}$ & & $\begin{array}{l}0.188^{* *} \\
(0.013)\end{array}$ & $\begin{array}{c}0.188^{* *} \\
(0.013)\end{array}$ & $\begin{array}{l}0.177^{* *} \\
(0.015)\end{array}$ & $\begin{array}{c}0.175^{* *} \\
(0.015)\end{array}$ & $\begin{array}{c}0.175^{* *} \\
(0.015)\end{array}$ & $\begin{array}{c}0.176^{* *} \\
(0.015)\end{array}$ & $\begin{array}{c}0.175^{* *} \\
(0.015)\end{array}$ & $\begin{array}{l}0.207^{* *} \\
(0.021)\end{array}$ & $\begin{array}{c}0.208^{* *} \\
(0.021)\end{array}$ \\
\hline $\ln \bar{S}_{t}$ & & & $\begin{array}{c}-0.058^{* *} \\
(0.018)\end{array}$ & $\begin{array}{c}-0.061^{* *} \\
(0.019)\end{array}$ & & & $\begin{array}{c}-0.128^{* *} \\
(0.018)\end{array}$ & $\begin{array}{c}-0.103^{* *} \\
(0.018)\end{array}$ & & $\begin{array}{c}0.092^{+} \\
(0.055)\end{array}$ \\
\hline $\ln \bar{W}_{t}$ & & & & & $\begin{array}{l}1.107^{* *} \\
(0.227)\end{array}$ & & & $\begin{array}{c}0.992^{* *} \\
(0.260)\end{array}$ & $\begin{array}{c}-0.464 \\
(0.451)\end{array}$ & \\
\hline $\ln \bar{C}_{t}$ & & & & & $\begin{array}{c}0.157^{*} \\
(0.074)\end{array}$ & $\begin{array}{c}0.421^{* *} \\
(0.071)\end{array}$ & $\begin{array}{l}0.501^{* *} \\
(0.072)\end{array}$ & $\begin{array}{l}0.325^{* *} \\
(0.074)\end{array}$ & $\begin{array}{l}0.182^{+} \\
(0.094)\end{array}$ & \\
\hline $\ln \bar{C}_{t}^{U S}$ & & & & & & $\begin{array}{c}0.000 \\
(0.015)\end{array}$ & $\begin{array}{c}0.027^{+} \\
(0.015)\end{array}$ & $\begin{array}{c}-0.011 \\
(0.017)\end{array}$ & $\begin{array}{l}-0.029 \\
(0.034)\end{array}$ & $\begin{array}{l}-0.010 \\
(0.030)\end{array}$ \\
\hline Observations & 23187 & 23187 & 23187 & 20461 & 20461 & 20461 & 20461 & 20461 & 12454 & 12454 \\
\hline Adjusted $R^{2}$ & 0.192 & 0.266 & 0.267 & 0.237 & 0.241 & 0.239 & 0.242 & 0.243 & 0.199 & 0.199 \\
\hline
\end{tabular}

Note: Robust standard errors in parenthesis. Significance levels: $+\mathrm{p}<0.10,{ }^{*} \mathrm{p}<0.05,{ }^{* *} \mathrm{p}<0.01$. Quadratic time trend and firm fixed effects included in all specifications. Specifications from column (4) are until 2005.

For consistency, column (4) repeats the specification in column (3), but using data until 2005 only. 
increase in $\left.\bar{C}_{t}^{U S}\right) \cdot{ }^{21}$. We find evidence that more competition for white collar workers and local managers (with somewhat weaker evidence for the more recent period 1990-2005 in columns (9) and (10)) has contributed to an increase in CEO pay, while global competition for managers does not appear to have contributed to an increase in pay in Germany. ${ }^{22}$

In Table 2 we re-estimate some specifications of Table 1 by allowing for lagged adjustments to better understand the dynamics of the responsiveness of compensation to changes in firm and market characterisitcs. Interestingly, we find that German CEO compensation responds now to a tighter global labour market for manager talent when we allow for a delay of one year but this effect is negligible. A 1 percent increase in US CEO pay increases CEO pay in Germany by 0.03 to 0.05 percent. CEO pay in Germany still adjusts, however, immediately and strongly to a tighter local labour market for manager talent. A 1 percent increase in average CEO pay in the local market increases CEO pay between 0.23 and 0.32 percent. Otherwise, we confirm the previous estimates of Table 1 with somewhat stronger effects of $S_{i, t}$ and $\bar{S}_{t}$ on CEO compensation when one year lags are included. ${ }^{23}$

To summarise, the presented evidence does seem to suggest that local competition for workers in general and for managers in particular has acted as a driving force behind the rise in CEO pay in Germany. We find also that the manager power hypothesis is supported by our analysis except for the great recession of 2009. The efficient pay hypothesis, however, is rejected by data, because the identified quest for manager talent does not appear to be coming from a shift in the size distribution of firms.

\footnotetext{
${ }^{21}$ We have data for average US CEO compensation only until 2005. Therefore, for transparency and clarity of results, in column (4) we have reported results from specification (3) but until 2005. It can be noted that the only significant change takes place for the coefficient for firm profits, which decreases in size and is not significant anymore.

${ }^{22}$ In this context, see Marin and Verdier (forthcoming), Marin (2009), and Cuñat and Guadalupe (2009) for the importance of international trade rather than a global labour market for managers for the rise in executive pay.

${ }^{23}$ We have tested further lags, but results do not substantially differ from those presented here.
} 
Table 2: Fixed Effects with Lagged Regressors

\begin{tabular}{|c|c|c|c|c|c|c|}
\hline & \multirow{2}{*}{$\begin{array}{c}1977-2009 \\
\text { (1) }\end{array}$} & \multicolumn{3}{|c|}{$1977-2005$} & \multicolumn{2}{|c|}{ 1990-2005 } \\
\hline & & (2) & $(3)$ & (4) & $(5)$ & $(6)$ \\
\hline No.Board $_{i t}$ & $\begin{array}{c}-0.068^{* *} \\
(0.010)\end{array}$ & $\begin{array}{c}-0.066^{* *} \\
(0.010)\end{array}$ & $\begin{array}{c}-0.067^{* *} \\
(0.010)\end{array}$ & $\begin{array}{c}-0.067^{* *} \\
(0.011)\end{array}$ & $\begin{array}{c}-0.064^{* *} \\
(0.012)\end{array}$ & $\begin{array}{r}-0.064^{* *} \\
(0.012)\end{array}$ \\
\hline No.Board $_{i t-1}$ & $\begin{array}{c}0.004 \\
(0.006)\end{array}$ & $\begin{array}{c}0.006 \\
(0.006)\end{array}$ & $\begin{array}{c}0.006 \\
(0.006)\end{array}$ & $\begin{array}{c}0.006 \\
(0.006)\end{array}$ & $\begin{array}{c}0.001 \\
(0.006)\end{array}$ & $\begin{array}{c}0.001 \\
(0.006)\end{array}$ \\
\hline$\pi_{t} / 1000$ & $\begin{array}{l}0.078^{*} \\
(0.037)\end{array}$ & $\begin{array}{c}0.058 \\
(0.042)\end{array}$ & $\begin{array}{c}0.058 \\
(0.042)\end{array}$ & $\begin{array}{c}0.058 \\
(0.042)\end{array}$ & $\begin{array}{c}0.053 \\
(0.041)\end{array}$ & $\begin{array}{c}0.053 \\
(0.042)\end{array}$ \\
\hline$\pi_{t-1} / 1000$ & $\begin{array}{l}0.031^{+} \\
(0.016)\end{array}$ & $\begin{array}{c}0.019 \\
(0.016)\end{array}$ & $\begin{array}{c}0.019 \\
(0.016)\end{array}$ & $\begin{array}{c}0.019 \\
(0.016)\end{array}$ & $\begin{array}{c}0.014 \\
(0.014)\end{array}$ & $\begin{array}{c}0.014 \\
(0.014)\end{array}$ \\
\hline $\bar{\pi}_{t} / 1000$ & $\begin{array}{l}0.463^{* *} \\
(0.084)\end{array}$ & $\begin{array}{c}0.362^{*} \\
(0.158)\end{array}$ & $\begin{array}{c}0.228 \\
(0.168)\end{array}$ & $\begin{array}{c}0.409^{*} \\
(0.193)\end{array}$ & $\begin{array}{c}0.271 \\
(0.283)\end{array}$ & $\begin{array}{c}0.250 \\
(0.283)\end{array}$ \\
\hline $\bar{\pi}_{t-1} / 1000$ & $\begin{array}{l}0.286^{* *} \\
(0.084)\end{array}$ & $\begin{array}{c}0.442^{*} \\
(0.190)\end{array}$ & $\begin{array}{l}-0.235 \\
(0.216)\end{array}$ & $\begin{array}{c}-0.116 \\
(0.215)\end{array}$ & $\begin{array}{c}0.004 \\
(0.236)\end{array}$ & $\begin{array}{c}0.076 \\
(0.245)\end{array}$ \\
\hline $\ln S_{t}$ & $\begin{array}{l}0.160^{* *} \\
(0.015)\end{array}$ & $\begin{array}{c}0.156^{* *} \\
(0.017)\end{array}$ & $\begin{array}{c}0.153^{* *} \\
(0.017)\end{array}$ & $\begin{array}{l}0.153^{* *} \\
(0.017)\end{array}$ & $\begin{array}{c}0.177^{* *} \\
(0.023)\end{array}$ & $\begin{array}{c}0.176^{* *} \\
(0.023)\end{array}$ \\
\hline $\ln S_{t-1}$ & $\begin{array}{l}0.064^{* *} \\
(0.010)\end{array}$ & $\begin{array}{c}0.063^{* *} \\
(0.011)\end{array}$ & $\begin{array}{c}0.064^{* *} \\
(0.011)\end{array}$ & $\begin{array}{l}0.064^{* *} \\
(0.011)\end{array}$ & $\begin{array}{c}0.072^{* *} \\
(0.016)\end{array}$ & $\begin{array}{c}0.072^{* *} \\
(0.016)\end{array}$ \\
\hline $\ln \bar{S}_{t}$ & $\begin{array}{l}-0.006 \\
(0.021)\end{array}$ & $\begin{array}{c}-0.004 \\
(0.022)\end{array}$ & $\begin{array}{c}-0.102^{* *} \\
(0.022)\end{array}$ & $\begin{array}{c}-0.082^{* *} \\
(0.025)\end{array}$ & & $\begin{array}{c}0.039 \\
(0.060)\end{array}$ \\
\hline $\ln \bar{S}_{t-1}$ & $\begin{array}{c}-0.107^{* *} \\
(0.019)\end{array}$ & $\begin{array}{c}-0.123^{* *} \\
(0.018)\end{array}$ & $\begin{array}{c}-0.123^{* *} \\
(0.022)\end{array}$ & $\begin{array}{c}-0.103^{* *} \\
(0.021)\end{array}$ & & $\begin{array}{c}0.001 \\
(0.055)\end{array}$ \\
\hline $\ln \bar{W}_{t}$ & & & & $\begin{array}{l}0.827^{*} \\
(0.409)\end{array}$ & $\begin{array}{l}-0.576 \\
(0.588)\end{array}$ & \\
\hline $\ln \bar{W}_{t-1}$ & & & & $\begin{array}{l}-0.333 \\
(0.351)\end{array}$ & $\begin{array}{c}0.181 \\
(0.506)\end{array}$ & \\
\hline $\ln \bar{C}_{t}$ & & & $\begin{array}{c}0.385^{* *} \\
(0.076)\end{array}$ & $\begin{array}{c}0.315^{* *} \\
(0.088)\end{array}$ & $\begin{array}{c}0.138 \\
(0.114)\end{array}$ & \\
\hline $\ln \bar{C}_{t-1}$ & & & $\begin{array}{c}0.108 \\
(0.077)\end{array}$ & $\begin{array}{c}0.026 \\
(0.085)\end{array}$ & $\begin{array}{l}-0.005 \\
(0.123)\end{array}$ & \\
\hline $\ln \bar{C}_{t}^{U S}$ & & & $\begin{array}{l}-0.013 \\
(0.019)\end{array}$ & $\begin{array}{r}-0.036^{+} \\
(0.022)\end{array}$ & $\begin{array}{c}0.006 \\
(0.040)\end{array}$ & $\begin{array}{c}0.028 \\
(0.039)\end{array}$ \\
\hline $\ln \bar{C}_{t-1}^{U S}$ & & & $\begin{array}{c}0.070^{* *} \\
(0.022)\end{array}$ & $\begin{array}{c}0.068^{* *} \\
(0.023)\end{array}$ & $\begin{array}{c}0.017 \\
(0.046)\end{array}$ & $\begin{array}{c}0.021 \\
(0.036)\end{array}$ \\
\hline Observations & 18560 & 16164 & 16164 & 16164 & 10292 & 10292 \\
\hline Adjusted $R^{2}$ & 0.292 & 0.262 & 0.267 & 0.267 & 0.220 & 0.220 \\
\hline
\end{tabular}

Note: Robust standard errors in parenthesis. Significance levels: $+\mathrm{p}<0.10,{ }^{*} \mathrm{p}<0.05,{ }^{* *} \mathrm{p}<0.01$. Quadratic time trend and firm fixed effects included in all specifications. Specifications from column (2) are until 2005. For consistency, column (2) repeats the specification in column (1), but using data until 2005 only. 


\section{$5 \quad$ Endogeneity}

In the previous section we did not allow for the possibility that our regressors $X_{i t}$ such as firm size, profits and other firm characteristics may be endogenous. However, the causality between CEO pay, firm size and profits is not entirely clear. Do firms pay their CEOs more in larger more profitable firms or do firms grow in size and in profitability when hiring more expensive (and presumable more able) CEOs? Moreover, CEO pay displays strong persistence over time (see Figure 1) which may reflect the composition of pay into a fixed part (strongly autocorrelated over time) and a variable part (which may or may not depend on firm's performance). As a consequence, lagged CEO compensation may well be an omitted variable in the static specification used in the previous section. We address these issues in this section. ${ }^{24}$

To assess the importance of biases associated with fixed effects and endogeneity we proceed with the following estimation techniques. In a first step, we include lagged compensation as a regressor to account for omitted variable bias (dynamic fixed effect estimation). In a second step, we use a "system" GMM estimation to account for unobserved heterogeneity in the model. ${ }^{25}$

We introduce a dynamic panel data model of the determinants of CEO pay by extending specification (1) to include the lagged dependent variable:

$$
\ln \left(C_{i t}\right)=\pi \ln \left(C_{i t-1}\right)+\sum_{j=0}^{1} \beta_{\mathbf{j}}^{\prime} \mathbf{X}_{\mathbf{i t}-\mathbf{j}}+\sum_{j=0}^{1} \gamma_{\mathbf{j}}^{\prime} \overline{\mathbf{X}}_{\mathbf{t}-\mathbf{j}}+\eta_{i}+\alpha_{1} t+\alpha_{2} t^{2}+\varepsilon_{i t}
$$

Consistent estimation of equation (5) depends on whether we assume our set of covariates to be exogenous.

In a second stage, we consider the (realistic) possibility that the covariates $X_{i t}$ are

\footnotetext{
${ }^{24}$ Examples in the literature where persistency is explicitly accounted for include Conyon (1998) and Main et al. (1996). We also consider that there is at least one channel by which past and present CEO pay may affect firm characteristics (namely size and performance). As noted by Baranchuk et al. (2011), executives' talent itself can affect firm performance and size.

${ }^{25}$ See Arrelano and Bover (1995), Blundell and Bond (1998).
} 
correlated with the error term other than via fixed effects. In this case the within transformation estimator does not deliver consistent results for the coefficients on the $X_{i t}$ regressors. In particular, in the presence of dynamics and of endogenous regressors, both OLS and fixed effects estimates are inconsistent and instrumental variables are required. In the absence of ad-hoc external instruments, we can use a "system" GMM estimator (Arellano and Bover (1995), Blundell and Bond (1998)) for equation (5). Since we have an unbalanced panel, we use orthogonal deviations (Arellano and Bover (1995)) instead of first differences to overcome the possibility of losing too many observations. We also limit the number of lags used as instruments to one and two and "collapse" the matrix of instruments to avoid proliferation of (weak) instrument. ${ }^{26}$

Table 3 shows results for the dynamic specification using both fixed effects (left panel) and "system" GMM (right panel) estimators without (columns (1), (2), (5) and (6)) and with lagged adjustment (columns (3), (4), (7) and (8)) for our preferred specifications from Tables 1. Because market variables are highly collinear, including lagged values makes standard errors of GMM coefficients too large, reducing the robustness of these estimates. For this reason, we only include contemporaneous values of firm and market characteristics in this set of specifications.

As expected, contemporaneous CEO compensation is positively and significantly correlated with lagged compensation confirming that executive compensation is strongly autocorrelated over time. Compared to the static specifications we find in the dynamic specifications that the role of a tighter local and global market for talent for the rise in CEO pay is somewhat smaller, in particular in the "system" GMM specification with lags (see column 8$)^{27}$. All other estimates remain robust to the alternative estimation techniques. In particular, the manager power hypothesis is not and the efficient pay hypothesis is once more rejected by the data. All specifications in Table 3 indicate that CEOs in

\footnotetext{
${ }^{26}$ We use the STATA command xtabond2 developed by Roodman (2006) for these estimates.

${ }^{27} \mathrm{We}$ do not control here for average wages of white collar workers. This variable does not have a significant effect in the dynamic specification in table 2 and is strongly collinear with average firm size, making the system GMM estimates too unstable.
} 
Table 3: Dynamic FE and GMM - 1977-2009

\begin{tabular}{|c|c|c|c|c|}
\hline & \multicolumn{2}{|c|}{ Fixed Effects } & \multicolumn{2}{|c|}{ "System" GMM } \\
\hline & (1) & (2) & (3) & (4) \\
\hline $\ln C_{i t-1}$ & $\begin{array}{c}0.508^{* *} \\
(0.021)\end{array}$ & $\begin{array}{c}0.505^{* *} \\
(0.022)\end{array}$ & $\begin{array}{l}0.808^{* *} \\
(0.055)\end{array}$ & $\begin{array}{l}0.827^{* *} \\
(0.059)\end{array}$ \\
\hline No.Board $_{i t}$ & $\begin{array}{c}-0.048^{* *} \\
(0.005)\end{array}$ & $\begin{array}{c}-0.048^{* *} \\
(0.005)\end{array}$ & $\begin{array}{c}0.018 \\
(0.013)\end{array}$ & $\begin{array}{l}-0.001 \\
(0.011)\end{array}$ \\
\hline$\pi_{i t} / 1000$ & $\begin{array}{c}0.051 \\
(0.034)\end{array}$ & $\begin{array}{c}0.051 \\
(0.034)\end{array}$ & $\begin{array}{c}0.071 \\
(0.044)\end{array}$ & $\begin{array}{c}0.027 \\
(0.050)\end{array}$ \\
\hline $\bar{\pi}_{t} / 1000$ & $\begin{array}{l}0.560^{* *} \\
(0.119)\end{array}$ & $\begin{array}{l}0.249^{+} \\
(0.134)\end{array}$ & $\begin{array}{l}0.495^{* *} \\
(0.076)\end{array}$ & $\begin{array}{l}0.299^{+} \\
(0.166)\end{array}$ \\
\hline $\ln S_{i t}$ & $\begin{array}{c}0.120^{* *} \\
(0.011)\end{array}$ & $\begin{array}{c}0.120^{* *} \\
(0.011)\end{array}$ & $\begin{array}{c}0.085^{* *} \\
(0.024)\end{array}$ & $\begin{array}{l}0.089^{* *} \\
(0.025)\end{array}$ \\
\hline $\ln \bar{S}_{t}$ & $\begin{array}{c}-0.055^{* *} \\
(0.014)\end{array}$ & $\begin{array}{c}-0.097^{* *} \\
(0.015)\end{array}$ & $\begin{array}{c}-0.046^{* *} \\
(0.014)\end{array}$ & $\begin{array}{c}-0.092^{* *} \\
(0.016)\end{array}$ \\
\hline $\ln \bar{C}_{t}$ & & $\begin{array}{c}0.172^{* *} \\
(0.055)\end{array}$ & & $\begin{array}{c}0.054 \\
(0.071)\end{array}$ \\
\hline $\ln \bar{C}_{t}^{U S}$ & & $\begin{array}{l}0.038^{* *} \\
(0.012)\end{array}$ & & $\begin{array}{l}0.027^{*} \\
(0.013)\end{array}$ \\
\hline Observations & 18560 & 16164 & 18560 & 16164 \\
\hline Adjusted $R^{2}$ & 0.451 & 0.452 & & \\
\hline $\begin{array}{l}\text { sarganp } \\
\text { hansenp }\end{array}$ & & & $\begin{array}{l}0.000 \\
0.132\end{array}$ & $\begin{array}{l}0.016 \\
0.456\end{array}$ \\
\hline $\mathrm{AR}(1)$ test ( $\mathrm{p}$-value) & & & 0.000 & 0.000 \\
\hline $\mathrm{AR}(2)$ test (p-value) & & & 0.000 & 0.000 \\
\hline $\mathrm{AR}(3)$ test (p-value) & & & 0.872 & 0.784 \\
\hline Degrees of freedom & & & 15.000 & 17.000 \\
\hline
\end{tabular}

Note: Robust standard errors in parenthesis. Significance levels: $+\mathrm{p}<0.10,{ }^{*} \mathrm{p}<0.05$, ** $\mathrm{p}<0.01$. Quadratic time trend and firm fixed effects included in all specifications. Instruments for orthogonal deviations equation GMM-type: No.Board ${ }_{t-3}$, No.Board $t_{t-4}, \ln S_{t-2}, \pi / 1000_{t-1}, \pi / 1000_{t-2}$ all collapsed; instruments for levels equation GMM-type: $\Delta \ln C_{t-3}, \Delta \ln C_{t-4}, \Delta \pi / 1000_{t}, \Delta \ln S_{t-1}$ all collapsed. Specifications including $\ln \bar{C}_{t}^{U S}$ are for the period 1977-2005. 
Germany are rewarded when the market is doing well (and average profits of the industry are large) rather than when profits of their own firms are large. CEOs in Germany do not appear to be compensated for outperforming the market. Moreover, the relationship between firm size and compensation becomes substantially smaller confirming the hypothesis that at least a part of this relationship is spurious. Finally, all specifications suggest that CEOs in Germany are rewarded for managing the firm in difficult times when the average firm size drops rather than when it increases as is suggested by the efficient pay hypothesis. ${ }^{28}$

All the diagnostics for our GMM estimates are satisfactory. Following the xtabond2 procedure, we are able to use a limited number of instruments and overidentifying restrictions (a maximum of 17 in the most extensive specification). All Hansen tests for the validity of overidentifying restrictions support the adequacy of the models. Because the Arellano-Bond autocorrelation tests (Arellano and Bond (1991)) reject the absence of second-order serial correlation, we use lags 3 and 4 to instrument the lagged dependent variable (equation in levels).

\footnotetext{
${ }^{28}$ One reason why average CEO pay as a measure for the tightness of the local labour market for executives becomes insignificant in the "system" GMM is because it is highly correlated with average CEO compensation in the US (the correlation coefficient being 0.93). While this does not appear to affect the fixed effects results, it clearly affects the estimates of the standard errors in the "system" GMM.
} 


\subsection{Is Bank Compensation Different?}

During the recent financial crisis banks and financial institutions have been in the spotlight. CEOs in banks have been accused of greed taking on excessive risks in pursuit of profits. Moreover, the payout of large bonuses to executives in financial institutions such as HypoRealEstate, Commerzbank, and WestLB saved from bankruptcy by taxpayers' money are seen as a stark illustration that CEO pay is not connected to economic performance. In the US the explosion of CEO pay has taken place particularly in the financial sector and has provoked strong public reactions such as the Occupy Wall Street movement in the US. ${ }^{29}$ Can we find a similar development in Germany? In this section weexamine whether bank CEOs are indeed a special case and whether their compensation differs from the rest of the economy. We can answer this question, since about 19 per cent of the firms in our sample are banks.

Figure 5 shows the evolution of CEO pay for the total board as well as per board member in German banks and selected percentiles of bank CEO compensation. Until 1992 CEO compensation in the banking sector looks similar to compensation in the entire economy. However, the increase in CEO pay in banks in 1992-2000 has been more dramatic reaching almost $€ 700.000$ already in 2000 (with an annual increase of 11 percent). When the dot com bubble burst, the fall was also much steeper with pay falling below $€ 500.000$ in 2003. After 2004 compensation in banks recovered again but never again reached the peak level of the year 2000. Over the entire period 1977-2007 CEO pay in banks doubled from $€ 220.000$ to $€ 450.000$ which is a mild increase compared to a more than 3 fold increase in the total economy. As for the rest of the economy, the increase in CEO pay in banks is largely due to an increase of the top 5 percent of the best paid CEOs who reached pay levels of over $€ 2$ mio in the year 2000 (panel (b)).

Why has CEO pay in the banking sector increased less than in the economy? Why

\footnotetext{
${ }^{29}$ In the US, the financial sector paid much larger wages compared to the rest of the economy. The wage premium of the financial sector has been attributed to financial deregulation and its resulting attraction for human capital, see Philippon and Reshef (2009).
} 
has bank pay been so much more volatile after 1992? We turn to Figure 6 for an answer. It shows that the median and mean of the two possible drivers of CEO pay in banks firm size and profits - have increased much less and have been much more volatile after 1992 than in the rest of the economy. Deflated net median profits and bank size hardly increased during the three decades of 1977-2007. Net profits increased from $€ 8$ mio in 1992 to almost $€ 40$ mio in 1999 before collapsing to around $€ 5$ mio in 2001. After 2001 profits fluctuated around $€ 10$ mio and $€ 15$ mio before dropping again to about $€ 2$ mio at the onset of the financial crisis. Firm size shows a similar pattern of volatility after 1992 . Apparently, CEOs in banks in Germany benefited in particular from the dot com years as profits and bank balance sheets exploded but they gained less from the years before the financial crisis of 2008-2009. The CEO pay discount in banking is not as surprising as it may seem at first sight, since unlike the US Germany did not experience the same type of financial deregulation in the 1990s and banking and financial institutions in Germany are probably not the most attractive place for bright and talented managers as Wall Street is in the US. Moreover, Germany's great recession of 2009 has been triggered by a collapse of trade and financial flows rather than by a failure of the domestic financial sector per se. The financial sector in Germany suffered when the US financial crisis was globalized and reached Germany.

Figure 7 finally sheds further light on the CEO discount in the banking sector in Germany. With pay levels of over $€ 700.000$ in 2006, manufacturing and services are the highest paying sectors in Germany followed by banks (€ 550.000) and insurance companies (€ 520.000). It appears that the CEO premium in manufacturing and services is mainly driven by profits rather than by firm size, while the dramatic increase in banks' balance sheets appears not to be reflected in CEO compensation in banks.

In Table 4 we report estimates for the subsample of banks. Columns (1) and (2) show the results for the static model without and with lags included, while column (3) gives 
Figure 5: Board Compensation, 1977-2008

\section{Banks}

(a) Mean across firms

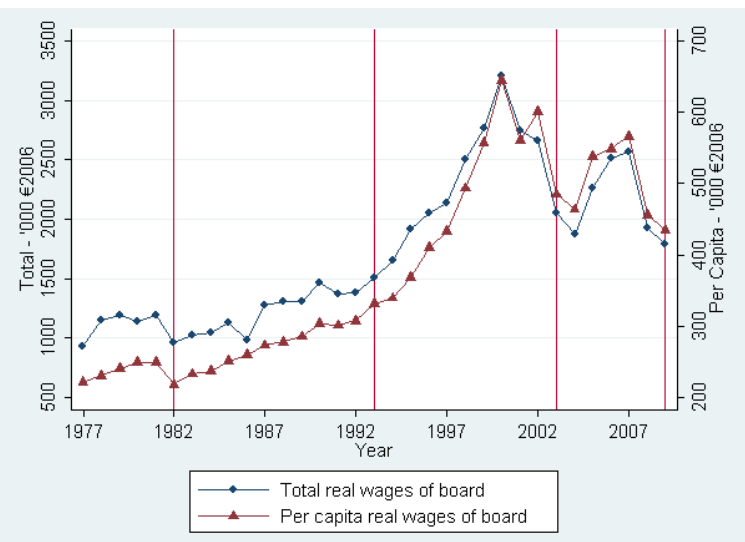

(b) Selected Percentiles

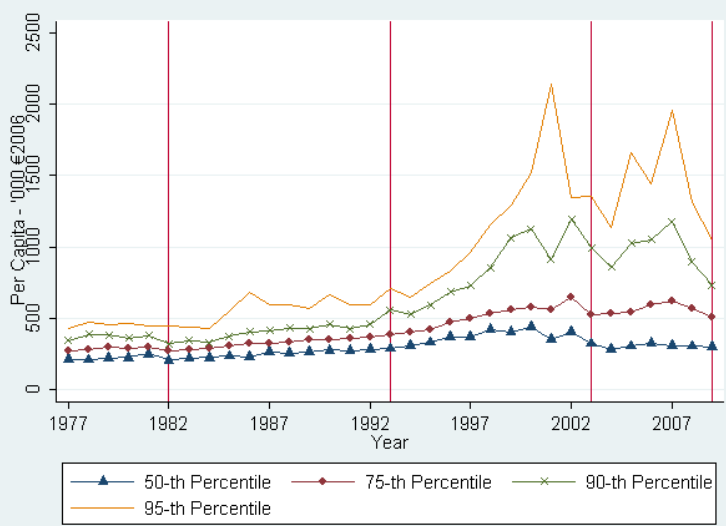

Note: Vertical bars indicate official recession years in Germany. Pay levels (in 2006-constant Euros) based on data for 500 largest public and limited liabilities companies. Total remuneration defined as the sum of salaries, bonuses, benefits, stock options, stock grants, and other compensation. Percentiles are evaluated for per capita real wages of board only.

Figure 6: Profits and Firm Size - 1977-2008

Banks

(a) Mean across Firms

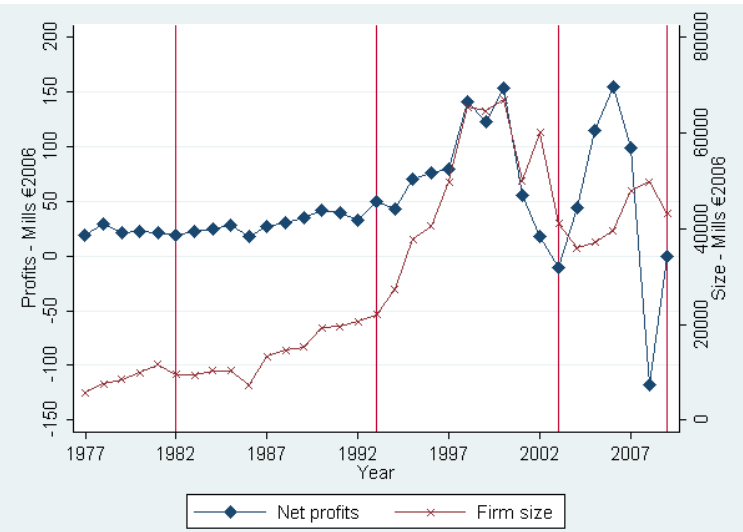

(b) Median across Firms

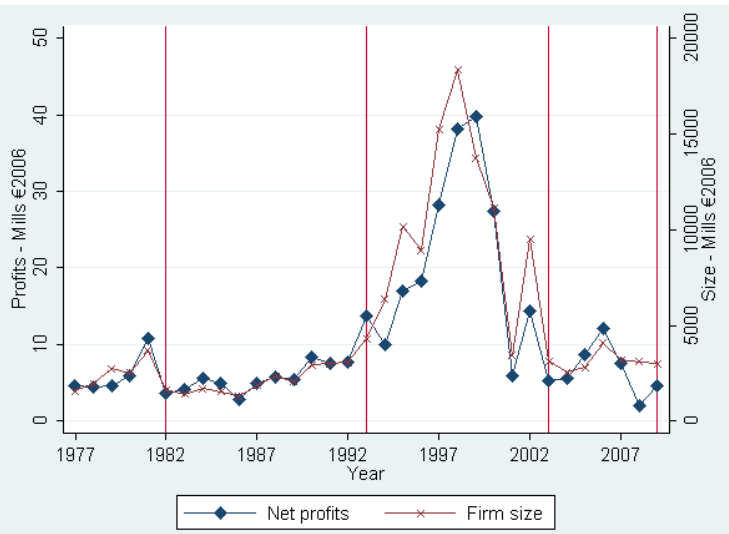

Note: Vertical bars indicate official recession years in Germany. Profits and size (in 2006-constant Euros) based on data for 500 largest public and limited liabilities companies. Profits are after tax. Size defined as balance sheet totals (banks), insurance premia (insurance companies), and sales (manufacturing and other services). 
Figure 7: Compensation, Firm Size and Profits by Sector: A Snapshot

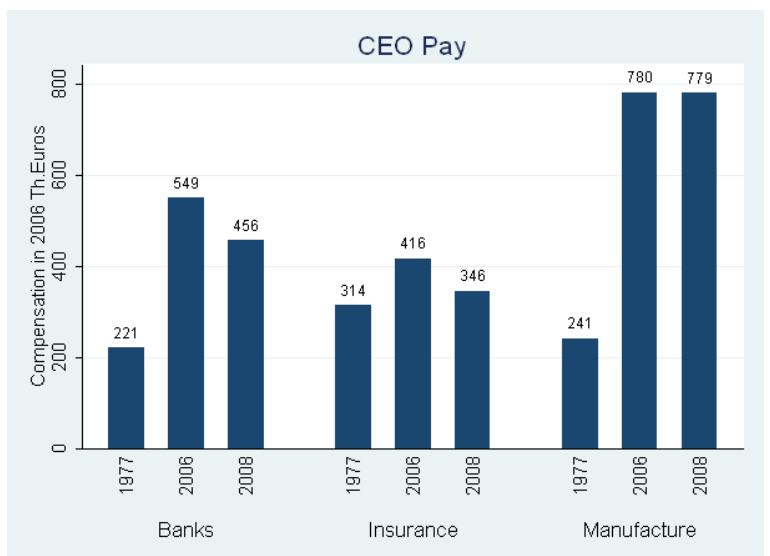

(b)
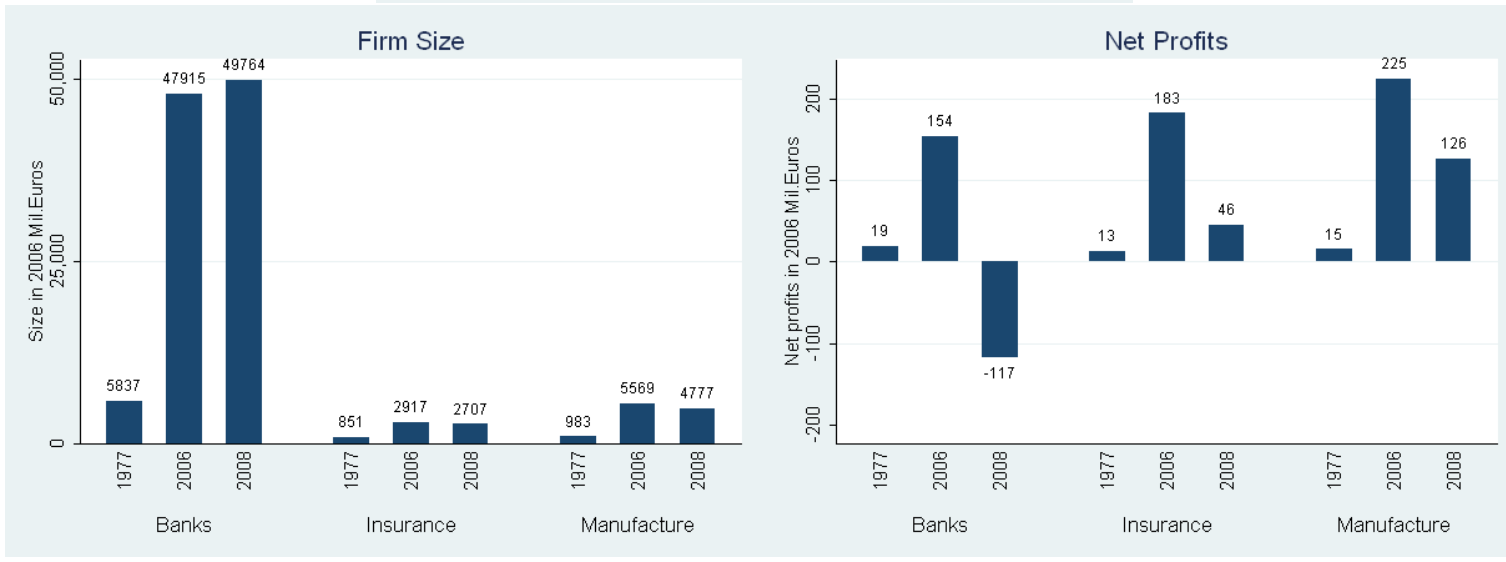

Note: Manufacture indicates manufacture and service sectors. Data is based on 500 largest public and limited liabilities companies. CEO remuneration (defined as the sum of salaries, bonuses, benefits, stock options, stock grants, and other compensation) is calculated as the total compensation of the executive board divided by the size of the board. Ratio to average compensation is defined as CEO compensation divided by earnings of full-time white-collar employees. 
Table 4: CEO Pay and Firm Characteristics: Fixed Effects without and with Lags Banks

\begin{tabular}{|c|c|c|c|c|c|c|}
\hline & \multicolumn{3}{|c|}{ 1977-2005 } & \multicolumn{3}{|c|}{ 1990-2005 } \\
\hline & (1) & (2) & $(3)$ & $(4)$ & $(5)$ & (6) \\
\hline $\ln C_{i t-1}$ & & & $\begin{array}{c}0.366^{* *} \\
(0.048)\end{array}$ & & & $\begin{array}{l}0.340^{* *} \\
(0.052)\end{array}$ \\
\hline No.Board $_{i t}$ & $\begin{array}{c}-0.051^{* *} \\
(0.018)\end{array}$ & $\begin{array}{c}-0.050^{* *} \\
(0.018)\end{array}$ & $\begin{array}{c}-0.046^{* *} \\
(0.014)\end{array}$ & $\begin{array}{c}-0.052^{*} \\
(0.023)\end{array}$ & $\begin{array}{c}-0.058^{* *} \\
(0.022)\end{array}$ & $\begin{array}{c}-0.050^{* *} \\
(0.016)\end{array}$ \\
\hline No.Board $_{i t-1}$ & & $\begin{array}{l}-0.005 \\
(0.014)\end{array}$ & $\begin{array}{c}0.013 \\
(0.012)\end{array}$ & & $\begin{array}{l}-0.006 \\
(0.014)\end{array}$ & $\begin{array}{c}0.011 \\
(0.011)\end{array}$ \\
\hline$\pi_{i t} / 1000$ & $\begin{array}{c}0.144^{* *} \\
(0.051)\end{array}$ & $\begin{array}{l}0.151^{* *} \\
(0.028)\end{array}$ & $\begin{array}{l}0.137^{* *} \\
(0.022)\end{array}$ & $\begin{array}{l}0.113^{* *} \\
(0.043)\end{array}$ & $\begin{array}{c}0.133^{* *} \\
(0.025)\end{array}$ & $\begin{array}{l}0.125^{* *} \\
(0.021)\end{array}$ \\
\hline$\pi_{i t-1} / 1000$ & & $\begin{array}{c}0.064 \\
(0.072)\end{array}$ & $\begin{array}{c}0.025 \\
(0.055)\end{array}$ & & $\begin{array}{c}0.052 \\
(0.070)\end{array}$ & $\begin{array}{c}0.021 \\
(0.055)\end{array}$ \\
\hline $\bar{\pi}_{t} / 1000$ & $\begin{array}{c}0.149 \\
(0.352)\end{array}$ & $\begin{array}{l}-0.204 \\
(0.485)\end{array}$ & $\begin{array}{c}0.239 \\
(0.457)\end{array}$ & $\begin{array}{c}0.605 \\
(0.459)\end{array}$ & $\begin{array}{c}-1.706^{*} \\
(0.833)\end{array}$ & $\begin{array}{l}-0.854 \\
(0.874)\end{array}$ \\
\hline $\bar{\pi}_{t-1} / 1000$ & & $\begin{array}{c}0.422 \\
(0.485)\end{array}$ & $\begin{array}{c}0.097 \\
(0.529)\end{array}$ & & $\begin{array}{c}1.460^{*} \\
(0.651)\end{array}$ & $\begin{array}{c}0.874 \\
(0.708)\end{array}$ \\
\hline $\ln S_{i t}$ & $\begin{array}{c}0.094^{* *} \\
(0.032)\end{array}$ & $\begin{array}{c}0.085^{*} \\
(0.035)\end{array}$ & $\begin{array}{l}0.065^{*} \\
(0.031)\end{array}$ & $\begin{array}{c}0.118^{* *} \\
(0.038)\end{array}$ & $\begin{array}{c}0.079^{*} \\
(0.036)\end{array}$ & $\begin{array}{l}0.056^{+} \\
(0.031)\end{array}$ \\
\hline $\ln S_{i t-1}$ & & $\begin{array}{c}0.026^{*} \\
(0.010)\end{array}$ & $\begin{array}{l}-0.003 \\
(0.014)\end{array}$ & & $\begin{array}{c}0.026 \\
(0.018)\end{array}$ & $\begin{array}{l}-0.009 \\
(0.018)\end{array}$ \\
\hline $\ln \bar{S}_{t}$ & $\begin{array}{c}-0.108^{* *} \\
(0.032)\end{array}$ & $\begin{array}{c}-0.194^{* *} \\
(0.046)\end{array}$ & $\begin{array}{c}-0.165^{* *} \\
(0.047)\end{array}$ & $\begin{array}{c}0.082 \\
(0.171)\end{array}$ & $\begin{array}{r}-0.495^{+} \\
(0.278)\end{array}$ & $\begin{array}{c}-0.431 \\
(0.320)\end{array}$ \\
\hline $\ln \bar{S}_{t-1}$ & & $\begin{array}{c}-0.107^{* *} \\
(0.038)\end{array}$ & $\begin{array}{c}-0.075^{*} \\
(0.037)\end{array}$ & & $\begin{array}{c}-1.214^{*} \\
(0.496)\end{array}$ & $\begin{array}{r}-0.941^{+} \\
(0.503)\end{array}$ \\
\hline $\ln \bar{W}_{t}$ & $\begin{array}{l}-0.327 \\
(0.438)\end{array}$ & $\begin{array}{l}-0.109 \\
(0.950)\end{array}$ & $\begin{array}{l}-0.059 \\
(0.968)\end{array}$ & $\begin{array}{l}-0.023 \\
(1.061)\end{array}$ & $\begin{array}{l}4.910^{+} \\
(2.615)\end{array}$ & $\begin{array}{c}3.693 \\
(2.371)\end{array}$ \\
\hline $\ln \bar{W}_{t-1}$ & & $\begin{array}{r}-1.125^{+} \\
(0.658)\end{array}$ & $\begin{array}{l}-1.104 \\
(0.699)\end{array}$ & & $\begin{array}{l}-3.077 \\
(1.872)\end{array}$ & $\begin{array}{l}-2.627 \\
(1.977)\end{array}$ \\
\hline $\ln \bar{C}_{t}$ & $\begin{array}{c}0.470^{* *} \\
(0.137)\end{array}$ & $\begin{array}{c}0.356^{*} \\
(0.175)\end{array}$ & $\begin{array}{c}0.280 \\
(0.180)\end{array}$ & $\begin{array}{c}0.389 \\
(0.264)\end{array}$ & $\begin{array}{c}0.986^{*} \\
(0.409)\end{array}$ & $\begin{array}{c}0.816^{*} \\
(0.403)\end{array}$ \\
\hline $\ln \bar{C}_{t-1}$ & & $\begin{array}{c}0.147 \\
(0.199)\end{array}$ & $\begin{array}{c}0.105 \\
(0.191)\end{array}$ & & $\begin{array}{c}1.299^{*} \\
(0.570)\end{array}$ & $\begin{array}{c}1.051^{*} \\
(0.532)\end{array}$ \\
\hline $\ln \bar{C}_{t}^{U S}$ & $\begin{array}{c}0.025 \\
(0.031)\end{array}$ & $\begin{array}{c}-0.024 \\
(0.049)\end{array}$ & $\begin{array}{l}-0.027 \\
(0.047)\end{array}$ & $\begin{array}{l}-0.118 \\
(0.073)\end{array}$ & $\begin{array}{c}0.286^{*} \\
(0.114)\end{array}$ & $\begin{array}{l}0.200^{+} \\
(0.119)\end{array}$ \\
\hline $\ln \bar{C}_{t-1}^{U S}$ & & $\begin{array}{l}0.157^{* *} \\
(0.044)\end{array}$ & $\begin{array}{l}0.135^{* *} \\
(0.044)\end{array}$ & & $\begin{array}{l}0.205^{+} \\
(0.105)\end{array}$ & $\begin{array}{c}0.168 \\
(0.107)\end{array}$ \\
\hline Observations & 3648 & 2772 & 2772 & 2220 & 1744 & 1744 \\
\hline Adjusted $R^{2}$ & 0.300 & 0.352 & 0.435 & 0.242 & 0.293 & 0.371 \\
\hline
\end{tabular}

28

Note: Robust standard errors in parenthesis. Significance levels: $+\mathrm{p}<0.10,{ }^{*} \mathrm{p}<0.05, * *$ $\mathrm{p}<0.01$. Quadratic time trend and firm fixed effects included in all specifications. 
the results of the dynamic fixed effect estimation. Columns (4) to (6) shows the same results for the period after German unification. We find several dimensions in which banks differ from other firms in the economy. First, banks provide incentives for their CEOs more than other firms. The estimated coefficient for profits of 0.14 is significant at the 1 percent level and it suggests that an increase in banks' relative profitability of 1 million Euros increases compensation for bank managers by 0.014 percent. Moreover, CEOs in banks are rewarded for performance rather than when the financial industry at large is doing well. Second, we find much stronger evidence that local and global competition for managers has been bidding up compensation for bank managers in Germany. A 1 percent increase in average CEO pay increases CEO pay by between 0.36 and 0.47 percent, and a 1 percent increase in average CEO wages in the US increases German CEO pay by 0.15 percent. The latter effect is almost 5 times larger in banks compared to the rest of the economy. Third, the effect of local and global competition for managers on CEO pay becomes much stronger after German unification in the period 1990-2005. The estimated coefficients double in size from 0.36 to .99 for local competition and from 0.15 to 0.50 for global competition.

\section{Conclusion}

This paper documents the evolution of CEO pay in Germany in the last three decades based on unique data of 500 largest German firms. CEO pay increased 3.2 fold in real terms over the period 1977-2009. We show that two potential drivers of CEO pay - the trend in profits and in firms size - can only partly account for the trend in CEO pay in Germany as firm size increased 6.5 fold and profits remained somewhat flat during the same period. In contrast to the US, we find a CEO discount in the German banking sector which appears to be driven by lower bank profits and perhaps by the fact that Germany did not experience the same type of financial deregulation as the US. We also find support for a stronger link between CEO pay and firm performance in the last financial crisis of 
2009 compared to previous recessions.

We then turn to a more rigorous analysis by testing two of the most prominent hypotheses of executive pay in the literature: the manager power hypothesis and the efficient pay hypothesis. Our findings can be summarized in the following points. First, we find support for the manager power hypothesis for Germany as executive compensation does not involve incentives for performance. German CEOs tend to be rewarded when the sector is doing well rather than the firm they work for. We reject however the manager power hypothesis for the financial sector and for the great recession in 2009 (especially when compared to previous recessions). Second, we reject the efficient pay hypothesis for the economy as a whole as well as for the financial sector as increases in the typical firm size do not contribute to increases in CEO pay. On the contrary, we find that CEO pay and the demand for manager talent increases in difficult times when the typical firm size shrinks, perhaps in an attempt of the firm to optimally limit losses. Third, we find strong and economically important evidence that domestic and global competition for managers has contributed to the rise in executive pay in Germany. Surprisingly, however, the impact of competition for managers on executive compensation has become weaker in the last two decades. Fourth, the effect of local and global competition for managers is particularly pronounced in the banking sector in particular in the last two decades.

Our results answer some questions but pose new ones. For example, we find a strong impact of domestic competition for managers on executive pay, but we cannot say where this effect of competition for managers is coming from, since we do not find evidence that a shift in the size distribution of firms has intensified the quest for manager talent. Further research is needed to answer this question.

\section{References}

Arellano, M. And S. Bond (1991): "Some Tests of Specification for Panel Data: Monte Carlo Evidence and an Application to Employment Equations," Review of Eco- 
nomic Studies, 58, 277-97.

Arellano, M. And O. Bover (1995): "Another look at the instrumental variable estimation of error-components models," Journal of Econometrics, 68, 29-51.

Baranchuk, N., G. MacDonald, And J. YAng (2011): "The Economics of Super Managers," Review of Financial Studies, 24, 3321-3368.

Bebchuk, L. A. And J. M. Fried (2003): "Executive Compensation as an Agency Problem," Journal of Economic Perspectives, 17, 71-92.

Blundell, R. AND S. Bond (1998): "Initial conditions and moment restrictions in dynamic panel data models," Journal of Econometrics, 87, 115-143.

Conyon, M. J. And J. Schwalbach (2000): "Executive Compensation: Evidence from the UK and Germany," Long Range Planning, 33, 504-526.

Conyon, M. M. (1998): "Directors' Pay and Turnover: An Application to a Sample of Large UK Firms," Oxford Bulletin of Economics and Statistics, 60, 485-507.

Cuñat, V. And M. Guadalupe (2009): "Globalization and the Provision of Incentives inside the Firm: The Effect of Foreign Competition," Journal of Labor Economics, 27, $179-212$.

Dell, F. (2005): "Top Incomes in Germany and Switzerland Over the Twentieth Century," Journal of the European Economic Association, 3, 412-421.

Dustmann, C., J. Ludsteck, And U. Schönberg (2009): "Revisiting the German Wage Structure," The Quarterly Journal of Economics, 124, 843-881.

Frydman, C. And D. Jenter (2010): "CEO Compensation," Annual Review of Financial Economics, 2, 75-102. 
Frydman, C. And R. E. SAKs (2010): "Executive Compensation: A New View from a Long-Term Perspective, 1936-2005," Review of Financial Studies, 23, 2099-2138.

Gabaix, X. And A. Landier (2008): "Why has CEO pay increased so much?" The Quarterly Journal of Economics, 123, 49-100.

Hall, B. J. And J. B. Liebman (1998): "Are CEOs Really Paid Like Bureaucrats?" The Quarterly Journal of Economics, 113, 653-691.

Jensen, M. C. And K. J. Murphy (1990): "Performance Pay and Top-Management Incentives," Journal of Political Economy, 98, 225-64.

Lawton, C. (2009): "BMW Links Executive Pay to That of its Line Workers," Spiegel Online.

Main, B., A. Bruce, And T. Buck (1996): "Total Board Remuneration and Company Performance," Economic Journal, 106, 162744.

Marin, D. (2009): "The Battle for Talent: Globalization and the Rise of Executive Pay," Bruegel working paper.

Marin, D. and T. Verdier (forthcoming): "Globalisation and the Empowerment of Talent," Journal of International Economics.

Martens, K.-P. (2003): Festschrift fr Peter Ulmer zum 70. Geburtstag am 2. Januar 2003, de Gruyter Recht, chap. Stand und Entwicklung im Recht der Stock-Options, $399-418$.

MurPhy, K. J. (1999): "Executive compensation," in Handbook of Labor Economics, ed. by O. Ashenfelter and D. Card, Elsevier, vol. 3, chap. 38, 2485-2563.

Philippon, T. and A. Reshef (2009): "Wages and Human Capital in the U.S. Financial Industry: 1909-2006," NBER Working Papers 14644. 
Piketty, T. And E. Saez (2006): "The Evolution of Top Incomes: A Historical and International Perspective," American Economic Review, 96, 200-205.

European Commission (2003): "Recommendation 2003/361/EC,"
in Competitiveness and Innovation Framework Programme, http://europa.eu/scadplus/leg/en/lvb/n26026.htm: EUROPA.

Roodman, D. (2006): "How to Do xtabond2: An Introduction to "Difference" and "System" GMM in Stata," Working Papers 103, Center for Global Development. 


\section{Appendix: Data}

Table 5: Variable Description

\begin{tabular}{|c|c|c|}
\hline Variable Name & Description & Notes \\
\hline$C_{i t}$ & $\begin{array}{l}\text { Per capita remuneration of the execu- } \\
\text { tive board at time } t \text {, in thousands of } \\
2006 \text { Euros }\end{array}$ & $\begin{array}{l}\text { It includes monetary and non- } \\
\text { monetary compensations, therefore } \\
\text { values of (fringe) taxable bene- } \\
\text { fits, long- and mid-term incentives } \\
\text { (stock options, performance shares, } \\
\text { restricted stocks etc.), short-term } \\
\text { incentives (profit participation on } \\
\text { annual profits, mainly results-oriented } \\
\text { royalties) and fixed salary. }\end{array}$ \\
\hline Board $_{i t}$ & $\begin{array}{l}\text { Average number of members in execu- } \\
\text { tive board in year } t\end{array}$ & \\
\hline$S_{i t}$ & $\begin{array}{l}\text { Size of firm at time } t \text {, in millions of } \\
2006 \text { Euros }\end{array}$ & $\begin{array}{l}\text { Measured as balance sheet totals for } \\
\text { banks, insurance premia for insurance } \\
\text { companies and sales for manufactur- } \\
\text { ing and services. Balance sheet totals } \\
\text { and sales refer to the Allgemeinege- } \\
\text { sellschaft or, in the case of a control- } \\
\text { ling company, to the consolidated fig- } \\
\text { ures. }\end{array}$ \\
\hline$\overline{S_{t}}$ & $\begin{array}{l}\text { Size of average firm in the market at } \\
\text { time } t \text {, in millions of } 2006 \text { Euros }\end{array}$ & \\
\hline$\pi_{i t}$ & $\begin{array}{l}\text { Firm profits (after tax) at time } t \text {, in } \\
\text { millions of } 2006 \text { Euros }\end{array}$ & \\
\hline $\bar{\pi}_{t}$ & $\begin{array}{l}\text { Net profits of average firm in the mar- } \\
\text { ket at time } t \text {, in millions of } 2006 \text { Euros }\end{array}$ & \\
\hline $\bar{W}_{t}$ & $\begin{array}{l}\text { Average yearly wage of male employees } \\
\text { in the German economy at time } t \text {, in } \\
\text { thousands of } 2006 \text { Euros }\end{array}$ & $\begin{array}{l}\text { Data from German quarterly earnings } \\
\text { survey. }\end{array}$ \\
\hline $\bar{C}_{t}$ & $\begin{array}{l}\text { Average yearly per capita board com- } \\
\text { pensation at time } t \text {, in thousands of } \\
2006 \text { Euros }\end{array}$ & \\
\hline $\bar{C}_{t}^{U S}$ & $\begin{array}{l}\text { Average yearly remuneration of top } \\
\text { three CEOs in large US companies }\end{array}$ & Available until 2005 \\
\hline
\end{tabular}


Table 6: Descriptive Statistics

\begin{tabular}{l|cccccc}
\hline \hline & \multicolumn{7}{|c}{ All Firms - 1977-2009 } \\
& Count & Mean & Median & SD & Min & Max \\
\hline No.Board & 22546 & 3.982 & 3.500 & 2.159 & 0.330 & 67.000 \\
$C$ & 22546 & 378.932 & 278.665 & 445.563 & 0.025 & 17870.758 \\
$S$ & 22546 & 7580.108 & 687.689 & 42836.260 & 0.084 & 2099145.000 \\
$\pi$ & 22546 & 57.872 & 7.679 & 387.774 & -25747.432 & 11291.259 \\
$\bar{W}$ & 22546 & 34794.763 & 35138.281 & 3350.669 & 28519.418 & 39072.000 \\
\hline \hline & \multicolumn{7}{c}{ All Firms - 1997-2009 } \\
& Count & Mean & Median & SD & Min & Max \\
\hline No.Board & 8825 & 4.067 & 3.750 & 2.061 & 0.830 & 67.000 \\
$C$ & 8825 & 531.975 & 366.090 & 635.014 & 1.420 & 17870.758 \\
$S$ & 8825 & 12882.207 & 1093.538 & 64248.991 & 0.084 & 2099145.000 \\
$\pi$ & 8825 & 104.889 & 14.777 & 595.218 & -25747.432 & 11291.259 \\
$W$ & 8825 & 38091.103 & 38842.402 & 1051.712 & 36035.223 & 39072.000 \\
\hline \hline \multicolumn{7}{|c}{ Banks - 1977-2009 } \\
& Count & Mean & Median & SD & Min & Max \\
\hline No.Board & 4210 & 3.798 & 3.000 & 2.090 \\
$C$ & 4210 & 390.350 & 282.384 & 475.287 & 9.354 & 8687.227 \\
$S$ & 4210 & 30529.121 & 3335.662 & 94539.537 & 2.915 & 2099145.000 \\
$\pi$ & 4210 & 47.262 & 8.779 & 352.486 & -6031.684 & 6366.125 \\
\hline \hline \multicolumn{7}{c}{ Banks - 1997-2009 } \\
& Count & Mean & Median & SD & Min & Max \\
\hline No.Board & 1853 & 3.797 & 3.000 & 1.755 \\
$C$ & 1853 & 527.811 & 348.417 & 664.747 & 43.365 & 8687.227 \\
$S$ & 1853 & 48388.481 & 4103.043 & 132870.930 & 9.562 & 2099145.000 \\
$\pi$ & 1853 & 63.913 & 10.288 & 518.727 & -6031.684 & 6366.125 \\
\hline \hline
\end{tabular}

